\title{
Factors to Consider when Enhancing the Use of Web 2.0 Technologies in Higher Education: Students' and Lectures' Views for Quality Use
}

\author{
Razep Echeng, Abel Usoro, Isaiah Ewuzie \\ University of the West of Scotland, UK
}

\begin{abstract}
Learning quality enhancement with Web 2.0 tools needs good implementation framework and lessons from best practice. However, there is not much research on what constitutes best practice in the implementation of Web 2.0 in learning activities. This research seeks to contribute to research in this area by seeking the views of students on increased adoption of Web 2.0 social tools in learning activities. The research reports on the observational study carried out in one university in Scotland and a quantitative study carried out in the first stage of the research. The research reveals that an increase in the use of Web 2.0 tools in higher education is positively related to perceived usefulness, perceived ease of use, prior knowledge, motivation to use, social factors and performance expectancy. The findings in this research show students and lecturers' views on how increased use of Web 2.0 technology tools for learning in higher education can be achieved.
\end{abstract}

\section{Introduction}

Learning quality enhancement with Web 2.0 tools needs good implementation framework [1]. However, there is the need to seek for best ways to have successful implementation and not much research on good practice and its results are reported in literature. It has been observed that since 2005 the main effect of the initiative of technology enhanced learning in England, Scotland and Wales has been to bring to the knowledge of the institutions the relationship between technology provision, the use of technology and its impact on students learning [2]. Research shows that the impact of using technology in learning is hard to distinguish from the effect of other supports that may accompany its use, especially when pedagogical changes that take place have no relationship with technology [2]. It is certain and evident, though, that higher education can be transformed significantly through changes in the way learners and teachers understand and play their roles in learning and teaching activities, with or without technology [3] hence, the need to evaluate learning quality after introducing a new technology. The rest of this paper will present the literature review, the problem of study, the research questions, the method adopted to answer the questions, data collection, analysis, discussions, key findings, conclusion, limitations and future studies.

\section{Literature}

\subsection{Constructivist view of Learning with Web 2.0 Tools}

Learning with technologies make learning more active, social, reflective and in context [4]. However, the gap in knowledge is in the design practice of what should happen and what actually happens in technology enhanced learning [5]. Constructivist's view of learning is useful and promises development in evolving instructional design [6]. Although literature reveals that there are arguments amongst researchers on the validity of the constructivist approach on the use of Web 2.0 technologies, few researchers exist who agree with the constructivist view on learning with technology and they also report effective implementation strategies for students and teachers [1][7][8][9]. This view of learning is important in research because the underlying foundation aligns with the corresponding method that helps learners to make linkages between functional requirements of everyday life and the knowledge gained from potential learning experiences [10][11] One of the greatest challenges of technology in learning is determining whether it will provide real world contexts that engage learners in complex problem solving. Research has shown that the use of Web 2.0 technologies such as blogs, wikis and podcasts provide learners with opportunities to be involved in their learning, generating connections with their prior knowledge and linking it with the present activity as they communicate, reflect and discuss using blogs, discussion forums or any other platform [12] [4]. Active learning helps learners to develop ideas and this brings about meaningful learning. 


\subsection{Meaningful Learning}

Learning becomes more meaningful when it involves demonstrating competence and increasing participation in contributing to a social community [4]. Thus, meaningful learning can be achieved with the use of dialogue-based Web 2.0 technologies e.g. blogs and discussion forums will increase relationships among groups of learners and also it is a way to enhance the social basis for learning [9]. Meaningful learning occurs when learners engage in active, constructive, intentional, authentic, and cooperative learning and this is the primary and ultimate goal of education [9].

\subsection{Reflection in Learning}

Reflection in learning is a very important way of supporting learning [4]. Feedback from peers and lecturers can help students to reflect. If reflection is done every day or week it can improve their critical thinking skills [13][14]. Reflection takes place in an individual learner's personal learning or as a part of a broader dialogue, within the context of the class or of social interactions with peers and teachers or trainers. Hence, introducing Web 2.0 tools for learning activities can enhance reflection in a group activity. Driscoll [4] acknowledged that integrating new experiences with prior knowledge and reflecting upon this process helps to build new mental models and create new meanings.

\subsection{Web 2.0 Technologies Integration}

Redecker et al. [16] confirm that many institutions are integrating Web 2.0 technology tools to support students' learning and to support students' engagement in learning activities. However, integration of these technologies to be used in these institutions will depend on (1) realistic policies; (2) organizational support; and (3) integration planning [16], [17]. Jucevičienè and Valinevičienè [7] observed in their research and concluded that there are four main factors that determine adoption of social network usage in higher education: (1) academic service support, (2) student support (3), social and cooperate learning, and (4) achievement presentation. However, not much research has reported using these implementations strategies and choice of platforms.

\subsection{Choice of Platform or Tools to Use}

Kennelly's research [8] suggested that decision on the tools to be used for online learning should be based on two criteria: (1) students should be comfortable with an interface; and (2) it should be associated with their learning styles. Kennelly recommended platform environments such as course management systems as being very useful to enhance the effective use of Web 2.0 technology in learning [8].

\section{Problem}

Literature reveals that meaningful learning involves demonstrating competence of increasing participation and contribution to a social community. Presently, many young persons are engaging with Web 2.0 technologies for social purpose and rarely transfer these skills for collaborative learning purpose. Hence, three research questions about factors that would increase Web 2.0 technology tools in learning activities in higher education were considered.

\subsection{Research Questions}

1. What are the views of students regarding the use of Web 2.0 social technologies in learning activities?

2. How can adoption of Web 2.0 tools be increased to achieve better students' learning experience?

3. How can these technologies be used effectively by students?

\section{Method}

This research used three sources of data collection: answers to closed ended questions, free comments in the survey and data from a focus group's discussion and interviews. A descriptive and content analysis of individual views from students who participated in the complimentary teaching with blogs in a LMS was used to explain their experience following-up on previous quantitative research study [18] in this educational institution. The qualitative data collection was carried out in order to find the extent to which the quantitative and qualitative approaches agree in this research [19]. An observational approach with a focus group and a survey with questionnaire (open and closed ended questions) were used to evaluate the focus group students. The observational study would be discussed in six stages as detailed in the next section.

\subsection{Stage 1: Introducing Blogs in Learning Activities}

The researchers introduced the use of blogs in a class (made up of college, undergraduate, postgraduate and company staff) in order to complement teaching and also to observe the students' behavior with the use of these tools. The students were told the importance of 
interaction and participation in all learning activities and also advised to communicate by asking questions, commenting and responding to posts from the teacher and from each other. The students were also told to look out for an invitation to join the class blog (see the link to the LMS that was set up for the students by the researchers: https://www.coursesites.com/webapps/login/?new_loc=/ webapps/portal/frameset.jsp).

\subsection{Stage 2: Starting a Group Blog}

The students were all registered on this learning management system (LMS) and their login details were generated and sent to them via email.

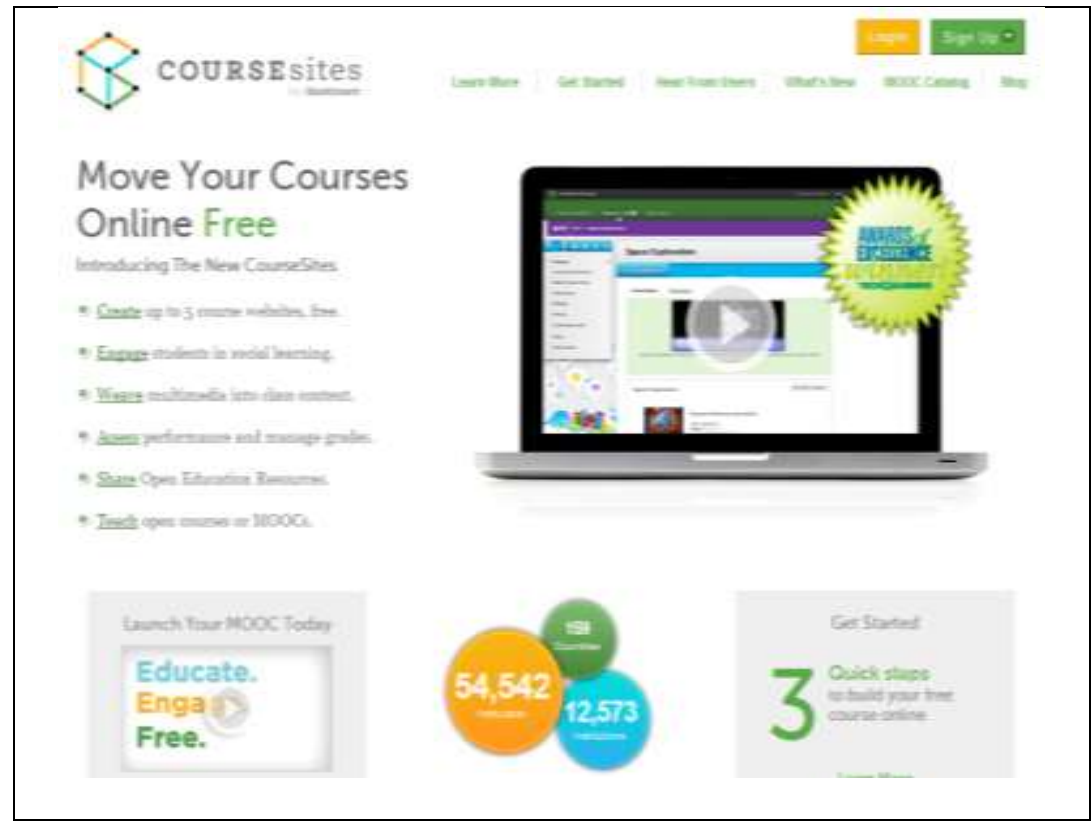

Figure 1. Login page for the LMS (course site)

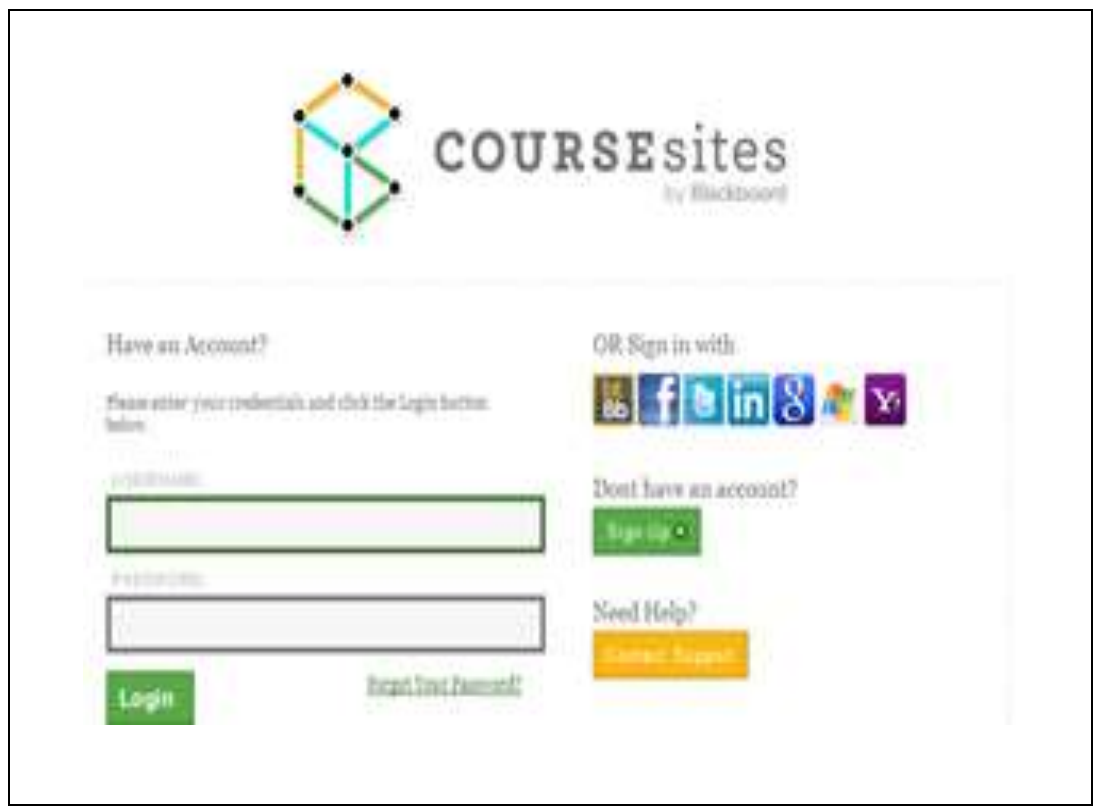

Figure 2. Username and password login 


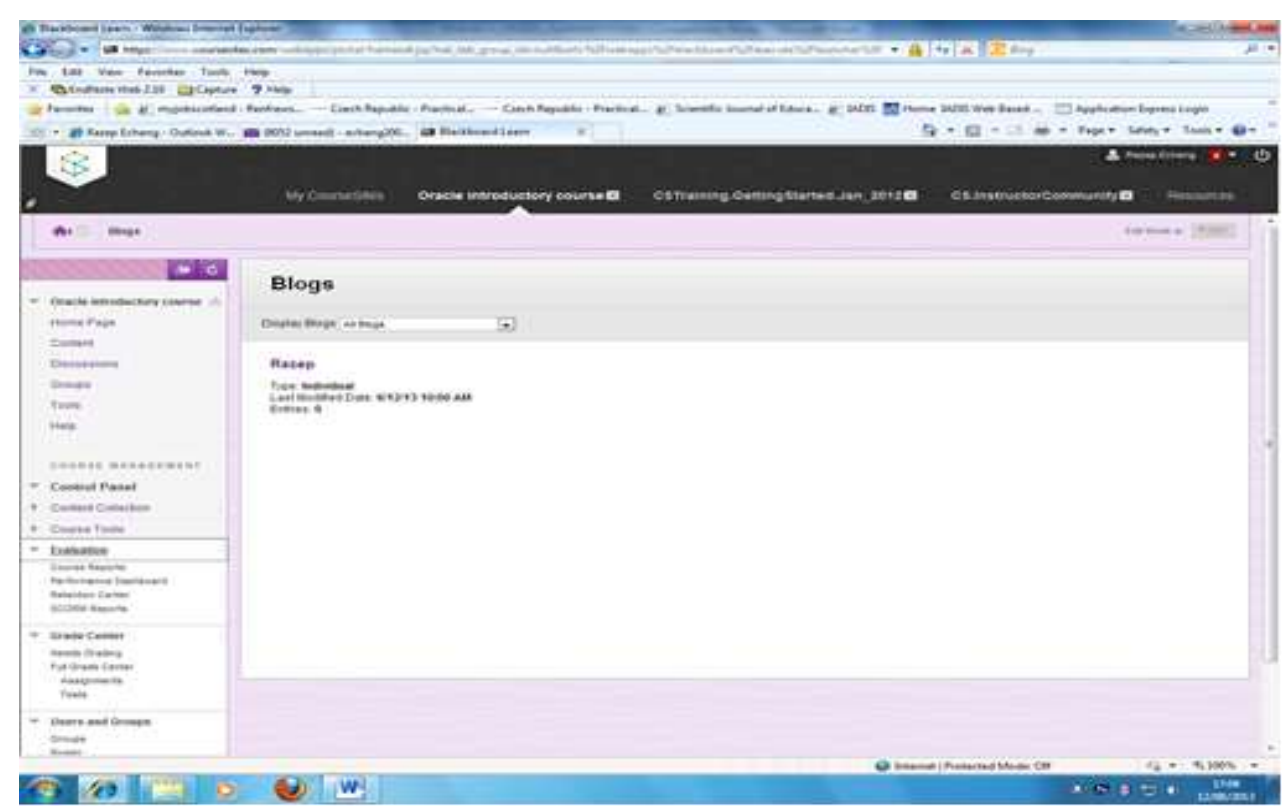

Figure 3. Group blog for Oracle database design

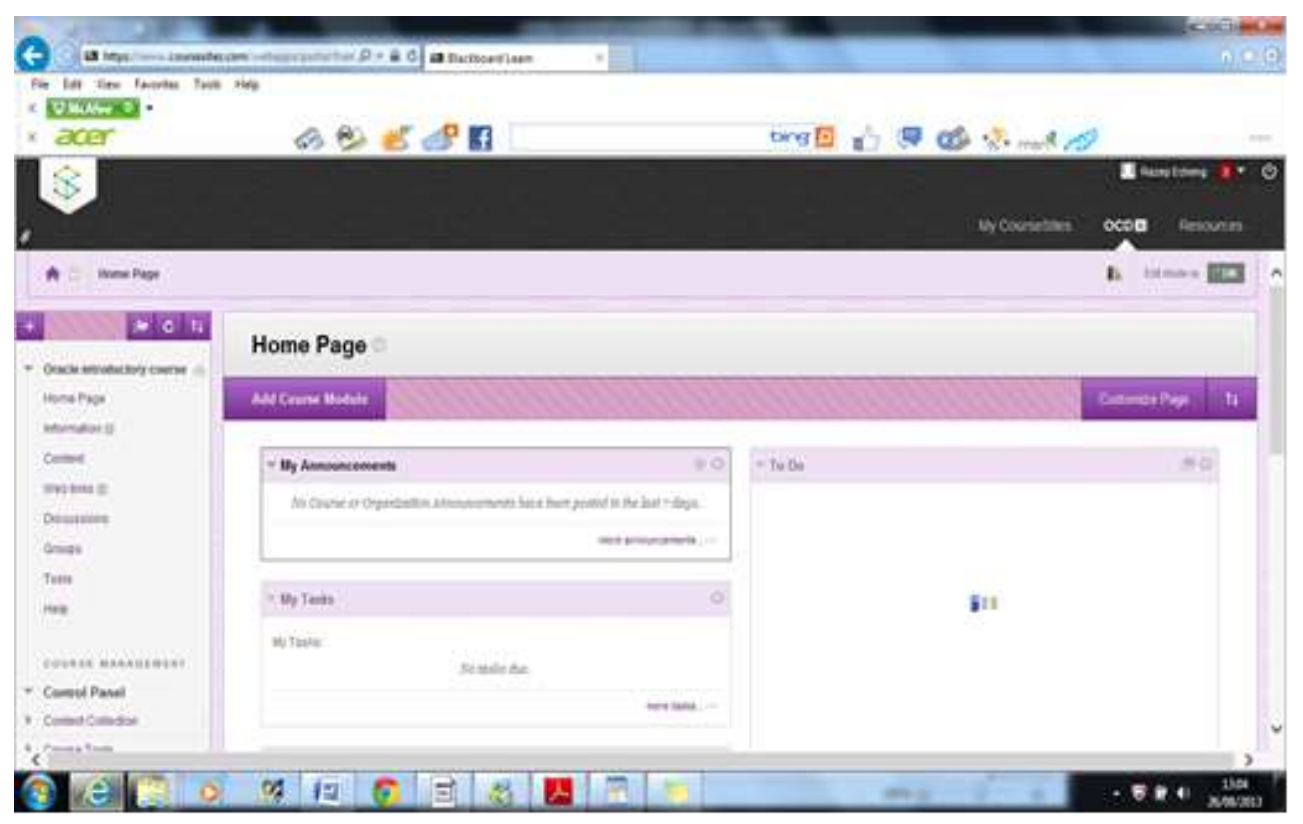

Figure 4. Announcements on the LMS

\subsection{Stage 3: Posting Blogs}

Blogging was used to complement lectures during the teaching of Oracle database and SQL. This medium was used to distribute objectives, summaries, and questions from the lecturer. The researchers started with very simple tasks and progressed to more difficult ones.

\subsection{Stage 4: Checking Blogs and Reminding Participants to Post}

The instructor also sent announcements and reminders on commenting and posting blogs. The researcher checked for invitation acceptance and also checked for the number of people who commented, read the posts or downloaded the labs and feedbacks. The teacher followed up students' participation (to enhance it) through sending emails to get them to blog. She also asked the students whether they were aware of 
blogging and its usefulness in learning. These questions were raised in the class and the majority of them raised their hands, indicating that they know about blogging. The lecturer followed up by asking how many of them blog. Only one hand was up. The students were encouraged to practice their coding in their personal blogs and also post blogs or questions in the class blogs; they were advised to ask questions any time using the group blog. The facilitator continued to post the usual weekly objectives, summary of lectures and questions on the teaching objectives to the LMS.

At the end of the module, out of ten (10) registered students, 3 students dropped out without attending any class and one (1) student was not regular, while six (6) attended classes regularly. At the end of the sixth week, the teacher observed that six (6) students were logged in the LMS every week, but none posted a blog or commented on the teacher's blogs; they rather downloaded their feedback and lab materials.

\section{Qualitative Data collection}

The lecturer interviewed the students in group discussions after they consented to participate in the research that took place in three universities in the United Kingdom. The group discussed their reasons for not posting blogs or commenting during the learning period using blogs. This discussion was audio recorded and it lasted for one hour. The researcher started with two questions which then led to other questions regarding how the constructs in the research affected their behaviour and how the constructs can be applied to enhance the use of the Web 2.0 tools for learning.

The questions were:

1. What were your reasons for not posting blogs or commenting?

2. What will motivate your participation and enhance your learning with blogs?

3. What support do you think students' need considering active, inactive and nonparticipatory students?

The questions were answered in a group discussion and their answers were analysed and summarised as discussed in the next section and in tables and figures showing evidence [20].

In analysing the answers, this research adopted a method used for observational study [20]. Four students had similar responses to the first question. They said that their lack of use was because it was not compulsory (no motivation to use) and also because participation with blogging did not attract any score or grade towards the professional certification they were studying for (no performance expectancy). One of them added that he would prefer to look up on the internet for what he does not understand or ask friends rather than discuss or ask the teacher (facilitating conditions and social factors).

Two students said that participation should have been graded and scores added to their final grades for the module since they were studying to gain university credit (motivation and performance expectancy) which would have served as motivation for quality contributions.

One student did not like the use of social tools for learning and he did not see himself using blogs in future or even using any social tool for learning. He still felt that it was not useful and that he preferred to read and understand rather than discussing with anybody and distracting himself.

In addressing the second question, five students suggested a phone app to make participation easy and quick.

These students suggested it would have been easier to blog with a simple app (ease of use) rather than an LMS. Blogging would have been better on their phones (facilitating conditions) because accessing the LMS always on their laptop before posting a blog was not something that was interesting or exciting (motivation, facilitating condition and ease of use) and there was no motivation especially because it was not compulsory. Two students said that they did not know how to use the platform to access the blogs (prior knowledge) and one added that it was not easy to access the blog tool in the LMS (ease of use and facilitating conditions). They added that if they were guided on how to get to the tools in the LMS platform or how to use the LMS generally they would have been motivated. However, they were not bothered because it was not compulsory to participate.

The students were also bothered about support and checking how they respond to questions for feedback and to encourage participation. These views are analyzed and presented in Tables 1, 2 and 3 .

Question 3 was addressed in different ways and their views are summarised in Table 2. This observational study with students yielded similar constructs unveiled in the quantitative study in the same university [21]. Further explanations on how these constructs can be applied in achieving increased use and improve the quality of learning with Web 2.0 tools were unveil in the students' discussion (see Table 3).

This research revealed that supporting student engagement is very important and this agrees with research by Baxter et al. [1]. Students' motivation (see Table 2) is also revealed and this is in line with lecturers' concern for quality use of technology [21]. Table 2 shows categories of users that could exist and how they can be supported for quality learning activities with Web 2.0 technologies 


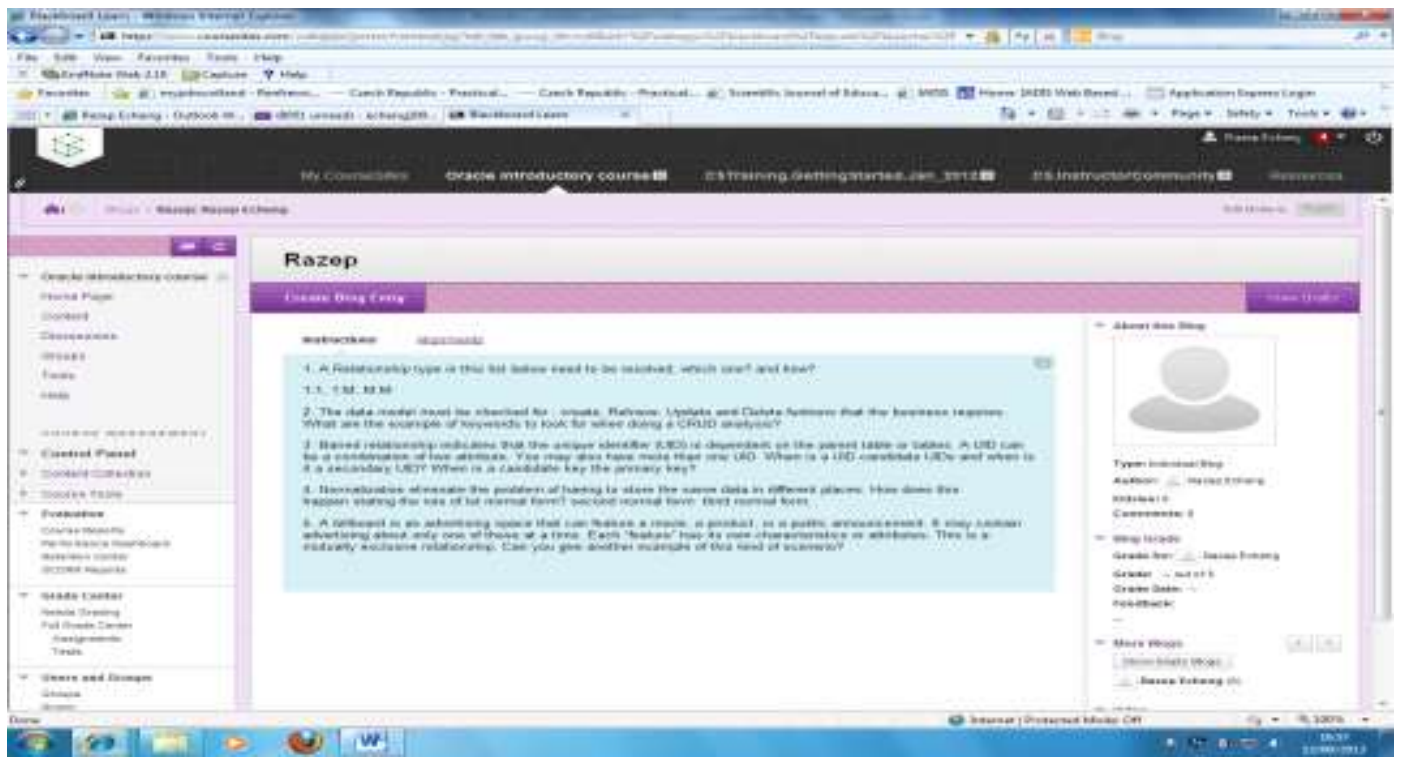

Figure 5. Database teaching with blogs

Table 2. Support to students

\begin{tabular}{|l|l|l|}
\hline Participants & Behaviour & Handling student support \\
\hline 1 & Copy and paste users & $\begin{array}{l}\text { a) Check for such responses. } \\
\text { b) Email and ask them to try to construct their knowledge from different sources and } \\
\text { always acknowledge their sources. }\end{array}$ \\
\hline 2 & $\begin{array}{l}\text { Little participation } \\
\text { users }\end{array}$ & $\begin{array}{l}\text { a) Email these users and assign roles to them. } \\
\text { b) The role they play online may stir up more participation. }\end{array}$ \\
\hline 3 & $\begin{array}{l}\text { Poor quality } \\
\text { contributors }\end{array}$ & $\begin{array}{l}\text { a) Discuss some of the posts and seek responses from others. } \\
\text { b) Allocate marks to participants so as to attract quality contribution. }\end{array}$ \\
\hline 4 & $\begin{array}{l}\text { Very active and quality } \\
\text { contributors }\end{array}$ & $\begin{array}{l}\text { Commend or congratulate the very active users and encourage them by assigning them } \\
\text { key online roles so that they would be motivated to keep contributing online. }\end{array}$ \\
\hline 5 & Very irregular users & $\begin{array}{l}\text { Check with them to be sure they have access to internet and send emails to them } \\
\text { encouraging them to participate. }\end{array}$ \\
\hline 6 & $\begin{array}{l}\text { Very active users with } \\
\text { prompt responses } \\
\text { which however lack } \\
\text { quality }\end{array}$ & $\begin{array}{l}\text { Assign key roles to them making them the last set of people to send input thereby } \\
\text { making these students to summarise quality input. }\end{array}$ \\
\hline
\end{tabular}

Table 3. Application of the Constructs in Implementation

\begin{tabular}{|c|c|}
\hline Construct & Implication \\
\hline Perceived usefulness & $\begin{array}{l}\text { Give users reasons for online collaboration and also tell them the usefulness of this participation in } \\
\text { their learning processes. }\end{array}$ \\
\hline Social factors & $\begin{array}{l}\text { Get students to start and move together in learning groups and encourage activities using } \\
\text { interventions such as emails. }\end{array}$ \\
\hline Motivation to use & $\begin{array}{l}\text { Encourage students to write constructively and also ask them to collaborate with others by giving } \\
\text { feedback to each other and participating in peer review. }\end{array}$ \\
\hline Behaviour & $\begin{array}{l}\text { Frequently check their online activities and encourage them to use Web technologies to support } \\
\text { themselves in their learning and to establish a network of learning using technologies. }\end{array}$ \\
\hline Facilitating conditions & $\begin{array}{l}\text { Ensure that users have access to institutional or personal ICT facilities; also support users at } \\
\text { different stages of learning activities when needed. }\end{array}$ \\
\hline Ease of use & $\begin{array}{l}\text { Ensure that the platforms or tools used for learning activities are reasonably easy (not requiring } \\
\text { much training effort) to serve as motivation to users, and this also enhances confidence and } \\
\text { frequency of use. }\end{array}$ \\
\hline Prior knowledge & Get users to be familiar with the platform or tools so that they are motivated to use it frequently. \\
\hline $\begin{array}{l}\text { Performance } \\
\text { expectancy }\end{array}$ & $\begin{array}{l}\text { Give users a clear importance of participation that relate with reward and expectation in } \\
\text { performance in test assignments, in order to motivate quality participation. }\end{array}$ \\
\hline
\end{tabular}




\section{Analysis of Qualitative Study}

After the implementation with blogs with 10 students who were registered to take Oracle Database and SQL in trimester three (a six weeks' programme), it was observed that there was still a low utilization of Web 2.0 interactive tools (group blogs) by students. The analysis also revealed the need for students to be guided at different stages in order for them to participate effectively. However, the surprising findings were in the evaluation of students' usage of the LMS. The students frequently accessed the LMS to download course content, lab materials but did not read the blogs or posted blogs; neither did they comment on the blogs posted by the instructor.

The qualitative study unveiled eight themes: ease of use, motivation, compulsion, training, guide, inadequacy of knowledge, relationship of the activities with their performance improvement, and support. The data also provided suggestion on how these constructs can be applied to increase the use of Web 2.0. These themes were similar to the constructs (see Table 3) measured in the first phase of this research using the survey. It also agrees with existing research [22], [23], [24]. The qualitative data validated the constructs in the quantitative data (see Table 3).

Table 3. Interview themes and survey constructs

\begin{tabular}{|l|l|}
\hline Themes in interviews & $\begin{array}{l}\text { Corresponding construct in } \\
\text { survey }\end{array}$ \\
\hline Not compulsory & Motivation \\
\hline No grades & Performance expectancy \\
\hline $\begin{array}{l}\text { Better blogs with mobile app } \\
\text { in mobile phone }\end{array}$ & Facilitating condition \\
\hline Not easy to use & Perceived ease of use \\
\hline Like to share with Friends & Social factors \\
\hline $\begin{array}{l}\text { Did not have much } \\
\text { understanding of blogging }\end{array}$ & Prior Knowledge \\
\hline
\end{tabular}

\section{Quantitative Study}

The quantitative study in previous study measured eight constructs: ease of use, motivation, facilitating condition, prior knowledge, social factor, performance expectancy and perceived usefulness. These constructs were validated with data collected from 270 participants (203 student and 76 lecturers [21].

\section{Comparison of the Quantitative and the Quantitative Study}

The qualitative data and the quantitative data analysis agree in this research. The quantitative data validated the constructs in the conceptual model in the first phase of the research [18] and also confirmed similar constructs in this qualitative study with explanation to understand how these constructs are implemented. Thus, the study developed an enhanced model of Web 2.0 acceptance as shown in Figure 6.

\section{Key Findings}

The qualitative data analysis revealed that technologies for learning activities need to be easily accessible, simple, easy to use, and have tools that are easy to find.

The students need guidance on how best to use and where to find these tools in the platforms (e.g. Learning Management systems (LMS)) especially if students are new to the system. This agrees with the work in existing research [16], [8].

The use of these tools for learning could be achieved when usage and participation is made mandatory.

Adding grades or scores on participation and commenting on post and adding the grade to overall students' performance would influence behavior in using these tools.

Attitude towards use can be enhanced where there is awareness. There should be provision of training on how to use these tools for those not familiar with the tools, platform, or application. This agrees with an existing research [1].

The tools or applications should be readily available online and offline to cater for those with limited internet facilities or poor internet signals.

Another implication for practice from this study is that adequate measures need to be put in place to encourage students and academics to use Web 2.0 technologies for learning. This also agrees with Baxter et al. [1] research.

\section{Conclusion}

The data collected were analysed and it confirmed the results of the analysis from previous quantitative survey with major constructs in the research model for effective use of Web 2.0 in learning activities [18]. The findings reveal that the constructs (perceived usefulness, facilitating conditions, prior knowledge, social factors perceived ease of use, performance expectancy) influence behavioural intention. These constructs are important factors that influence acceptance and effective use of Web 2.0 technology tools for learning. The interview results agree with the quantitative results that validated the research model which contained factors that would influence the use of Web 2.0 technologies in learning in higher education in Scotland. All the hypotheses of the model were validated. 


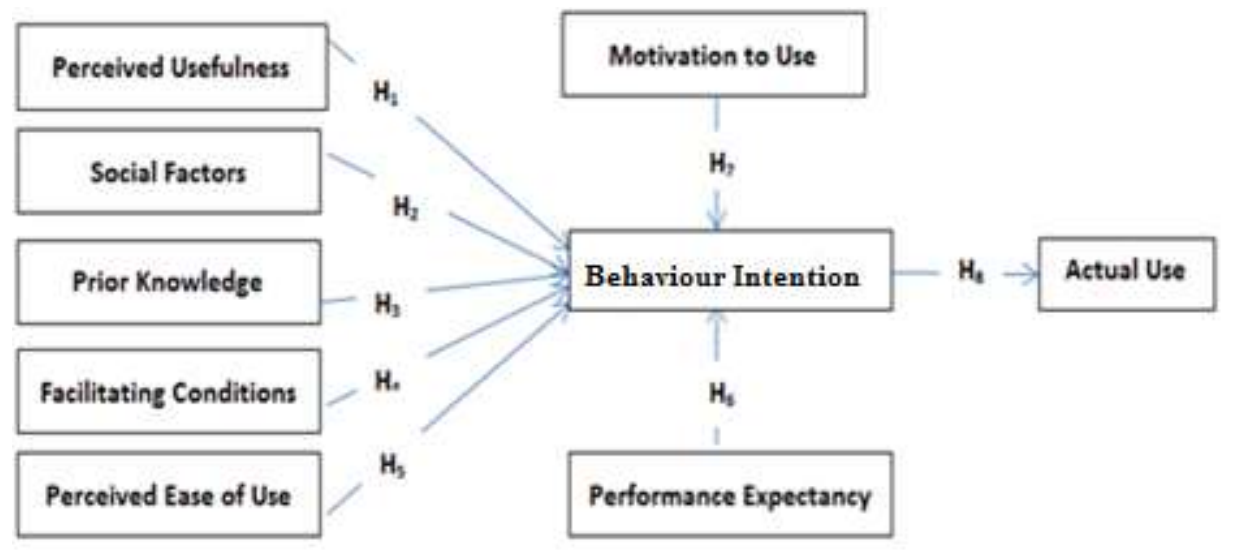

Figure 6. Enhanced model of Acceptance of Web 2.0 in learning in higher Education

The interviews conducted after the experimentation revealed that more than half of the students attributed their lack of use to three problems: not being easily accessible, not being motivated, and not perceiving the usefulness. One third of the students needed to be guided on using these technologies for effective learning. The students who needed guidance were not familiar with the platform and with using blogs for learning.

The research used the LMS evaluation tool and observed that the students frequently accessed the LMS but did not participate in posting blogs or commenting on the blogs posted by the lecturer and this was very surprising. A more comprehensive list of key factors observed to be accountable for failure of students to use these tools are scaffolding, support and guidance in addition to motivation, performance expectancy, ease of use and perceived usefulness.

The interviews also revealed that the students would have preferred informal interactive discussion forums (audio, text and video). This research agrees with existing research [1], [15], [19], [20], [21] on the view that quality learning with the use of Web 2.0 technologies for learning in higher education need intrinsic and extrinsic motivation, ease of use, perceived usefulness, facilitating condition as well as prior knowledge and support. A combination of these constructs was used to develop an enhanced model of acceptance and effective use of Web 2.0 technology (see Figure 6).

\section{Limitation and Future Studies}

The students were not the regular students and were not familiar with the LMS. These students were not trained due to the time required to finish the programme which was a six weeks' short course. They needed to be guided on how to use the platform. Thus this suggests a future experimentation which will be preceded by the training of teachers and students to encourage effective use of these technologies for learning.

\section{References}

[1] Baxter, G., Stansfield, M. and Connolly, T., (2011). Introducing Web 2.0 in education: A structured approach adopting a Web 2.0 implementation framework, Next Generation Web Services Practices (NWeSP), 2011 7th International Conference, 499-504.

[2] Joint research center. Annual report 2010, European commission. https://ec.europa.eu/jrc/sites/default/files/ jrc_ar_2010.pdf [Accessed: 02-01-2012].

[3] Fry, H., Ketteridge, S., and Marshall, S. (Eds.)., (2008). A handbook for teaching and learning in higher education: Enhancing academic practice. Routledge.

[4] Driscoll, M., (2002). Blended learning: Let's get beyond the hype. https://www-07.ibm.com/services/pdf/

blended_learning.pdf [Accessed: 09-07-2015].

[5] Hannafin, M. J, Hannafin, M. K., Land, S. and Oliver, K., (1997). Grounded Practice and the Design of Constructivist Learning Environment. ETR \& D. 45(3), 101-117.

[6] Cognition and Technology Group at Vanderbilt, (1991). Technology and the design of generative learning environments, Educational Technology 31(5), 34-40.

[7] Jucevičienè, P., Valinevičienè, G., (2010). A Conceptual Model of Social Networking in Higher Education, Electronics and Electrical Engineering - Kaunas: Technology, 6(102), $55-58$.

[8] Kennelly, P., (2009). An Online Social Networking Approach to Reinforce Learning of Rocks and Minerals. Journal of Geoscience Education, 57(1), 33-40. 
[9] Jonassen, D., (1999). Designing Constructivist Learning Environments. In C. M. Reigeluth (Ed.). Instructional Design Theories and Models: A New Paradigm of Instructional Theory, 11, 215-239

[10] Winn, W., and Snyder, D., (1996). Constructive perspectives in psychology. In D. Jonassen (Ed.), Handbook of research for educational communications and technology, New York, Simon and Schoster Macmillian 112-142.

[11] Duffy, T., and Cunningham, D., (1996). Constructivism: Implications for the design and delivery of instruction. In D. Jonassen (Ed.), Handbook of research for educational communications and technology New York: Macmillian, 170198.

[12] Richardson, W., (2006). Blogs, Wikis, Podcasts, and other powerful tools for classrooms. Thousand Oaks, CA: Sage.

[13] Xie, Y. and Shama, P., (2010). The effect of peerinteraction styles in team blogging on students cognitive thinking and blog participation, Journal of Educational Computing 42(4), 459-479.

[14]Atherton, J. S. (2013). Learning and Teaching; Reflection and Reflective Practice http://www.learningandteaching. info/learning/reflecti.htm [Accessed: 04-08-2014].

[15] Franklin, T. and Harmelen, M., (2007). Web 2.0 for content for learning and teaching in higher education, London: Joint Information Systems Committee, 2007.

[16] Redecker, C., (2011). Review of Learning 2.0 practices, Study on the Impact of Web 2.0 Innovations on Education and Training in Europe, 2009 Available online https://europa.eu/Publications/pub.cfm?id=2059 [Accessed: 25-11-2011].

[17] Redecker, C., K. Ala-Mutka, M. Bacigalupo, A. Ferrari and Punie, Y., (2009). Learning 2.0: The Impact of Web 2.0 Innovations on Education and Training in Europe. Final Report. JRC Scientific and Technical Report, EUR 24103 EN: http://ipts.jrc.ec.europa.eu/publications/pub.cfm?id=2899.

[Accessed: 25-11-2011]

[18] Echeng, R., Usoro, A. and Majewski, G., (2013) Acceptance of Web 2.0 in Learning in higher education: an empirical study of a Scottish University, WBC 2013 July conference proceedings on e-learning, 30-38.

[19] Zikmund, G., (2010). Business Research Methods, Mason, OH: Thomson/South Western, 2003.

[20] Stroup, D., Berlin, A., (2000). Meta-analysis of Observational Studies in Epidemiology. A Proposal for Reporting, Journal of American Medical Association, 283(15).

[21] Echeng, R. and Usoro, A., (2014). Empirical study on effective implementation of Web 2.0 technology tools in learning: Case study of three Nigerian Higher educations,
Proceedings of Science and information conference 2014. 927-932. http://thesai.org/SAIConference2014 [Accessed: 2009-14].

[22] Venkatesh, V., Morris, V., Davis, G and Davis, F., (2003). User acceptance of information technology: Toward a unified view, MIS Quarterly, 27(3), 425-478.

[23] Davis, F., Bagozzi, R and Warshaw, P., (1989). User Acceptance of Computer Technology: a comparison of two theoretical models, Management Science, 35,982-1003.

[24] Ajzen, I and Fishbein, M., (1980). Understanding attitudes and predicting social behavior, Englewood Cliff, NJ: Prentice Hall. 